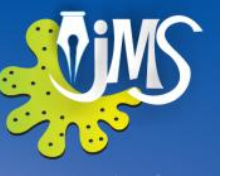

\title{
Seasonal occurrence of Microcystin-LR with respect to physico-chemical aspects of Beira lake water
}

\author{
Sumaiya F Idroos, Pathmalal M Manage* \\ Department of Zoology \\ University of Sri Jayewardenepura, Sri Lanka,
}

\begin{abstract}
Cyanobacteria are well known for their ability to produce a group of cyanotoxins referred as microcystins $(M C s)$. MCs show both acute and chronic hepatotoxic effects on animals and humans. Microcystin-LR $(M C L R)$ is the dominant type of MCs prevailing in Sri Lankan water bodies. The present study records the seasonal variation of MCLR, in the Beira lake waters from January 2013 to January 2014 with respect to some physico-chemical parameters of the lake. Quantification of MCLR was done using photodiode array High Pressure Liquid Chromatography method (PDA-HPLC). The physico-chemical parameters of the water body were measured using standard methods. Microcystis aeruginosa, Microcystis wesenbergii and Microcystis incerta, were the toxic cyanobacterial species present in the Beiralake while Microcystis aeruginosa (49.63\%) was the dominant species. MCLR concentration of the lake varied between $11.45 \pm 0.73$ to $17.57 \pm 0.13 \mu \mathrm{g} / \mathrm{ml}$ throughout the dry season of the sampling period while varied between $13.21 \pm 0.73$ to $25.23 \pm 0.42 \mu \mathrm{g} / \mathrm{ml}$ during the rainy season. The Pearsons correlation coefficient analysis done for total toxin concentration and the water quality parameters suggested that the water temperature $(r=0.914, p$ value $=0.000)$, and the total phosphate concentration $(r=0.988, p$-value $=0.000)$ have a strong positive correlation with the total MCLR concentration, while $p H(r=0.766, p$-value $=0.002)$ has a moderate correlation for the production of total MCLR.
\end{abstract}

KYWORDS: Cyanobacteria, Microcystin-LR (MCLR), Microcystis aeruginosa, Physico-chemical parameters, High Pressure Liquid Chromatography method (PDA-HPLC). 


\section{INTRODUCTION}

Cyanotoxins are a group of naturally produced biomolecules from several genera of cyanobacteria that occur in freshwaters around the world and have been well documented as a potential hazard to human health (Carmichael, 1995). Microcystins (MCs) are reported to be the most commonly occurring cyanotoxins found in water, and have been linked with poisonings of animals and humans exposed to contaminated water (Coddet al., 1989). Cyanobacteria, such as Microcystis sp, Anabaena sp, Planktothrix sp (Oscillatoria), Nostoc sp, and Hapalosiphon sp are mainly responsible for the production of MCs (Imanishi et al.,2004). The most common MC is Microcystin-LR (MCLR) that has the structure of cyclo (D-Ala-L-Leu-D-MeAsp-LArg-Adda-D-Glu-Mdha) (Carmichel, 1992).

The potency of MCLR in human was demonstrated in 1996 when 50 patients at a haemodialysis centre in Brazil died as a result of acute hepatic failure. It was discovered that the water used for dialysis had been contaminated with MCLR at concentrations high enough to cause severe liver damage (Jochimsen et al., 1998). Exposure to low levels of MCs in drinking water over a prolonged period may contribute to life threatening illnesses such as primary liver cancer through the known tumour-promoting activities of these compounds (Yu, 1994). In Southern China there are areas of very high rates of primary liver cancer, and epidemiological studies have linked this to drinking of surface water containing MCs (Elbenstein 2012). In another area in China, colon cancer rates have shown a correlation with concentration of MCs in the various water sources. Recent evaluation of carcinogenesis from MCs exposure by the international Agency for Research in Cancer has determined that MCLR and other MCs are possible carcinogens, based substantially on their demonstrable tumour promoting effects in laboratory studies with rodents (Ngwa et al., 2014).

A significant source of cyanobacterial toxin exposure is recreational use of contaminated fresh water bodies because large populations are likely to be exposed and toxins may occur in high concentrations. Initial epidemiologic studies did not focus on an association between recreational cyanobacteria exposure and adverse health effects (Phillip and Bates, 1992). More recently, Stewart et al. (2006b) found that people who used personal watercraft on lakes with high cyanobacteria concentrations (cell surface area> 12.0 $\mathrm{mm} 2 / \mathrm{ml}$ ) were 2.1 times more likely to report symptoms, particularly respiratory symptoms, than were persons who used their personal watercraft on lakes with low cyanobacteria concentrations (cell surface area $<2.4$ $\mathrm{mm} 2 / \mathrm{ml}$ ).

Environmental factors play an important role in the production of MCs. Field studies in South Africa (Wicks and Thiel, 1990) have shown that certain environmental factors are associated with the amount of toxins found in cyanobacterial blooms. Factors which are closely related to the growth of Microcystis have most commonly been selected to investigate their effects on the production of MCs. The effects of environmental factors on toxin production by cyanobacteria have also been shown by laboratory studies (Sivonnen, 1990).

Many authors have looked at the effects of physical, chemical and biological factors on 
the toxin production. Studies by Gorham (1964), Runnegar et al. (1983), and Van der Westhuizen and Eloff (1983) have demonstrated that temperature can have a marked effect on toxin production by $M$. aeruginosa in the $18-32{ }^{0} \mathrm{C}$ range, whereas Watanabe and Oishi (1985) and Ohtake et al. (1989) have found temperature in this range had no or little effect on toxin production. Much studies have been conducted on the relationship between prevailing ratios of nitrogen and phosphorus and the composition and density of phytoplankton assemblages. In 1986, Carmichael demonstrated that the emission of nitrogen causes approximately tenfold decrease in toxicity.

Most of the studies have concluded that toxicity (Codd et al., 1989) and toxin content of the cells (Watanabe et al., 1989) are highest at the late logarithmic growth phase. The effects of temperature (Codd et al., 1989) and light (Codd et al., 1988) on toxin production of $M$. aeruginosa were the most commonly studied parameters, and only a few studies consider the influence of other factors such as main nutrients (Watanabe and Oishi 1985) or pH (Van der Westhuizen and Eloff 1983). More information is needed regarding the influence of these factors on toxin production and growth of cyanobacteria to understand the dynamics of toxic blooms in nature.

Therefore, this study was undertaken to evaluate the seasonal variation of MCLR in Beira lake waters and relate them with the physico-chemical and biological properties of the lake water. The Beira Lake is situated within the city of Colombo, and covers 6 , $53,000 \mathrm{~m}^{2}$ with a catchment area of 4, 48, 000 $\mathrm{m}^{2}$. It has a history of severe cyanobacterial blooms. In May 2006, Sri Lankan media reported the deaths of a large number of fish and the presence of a heavy growth of algae in the Beira Lake (Magana-Arachchi et al., 2008). Moreover, the Beira lake is extensively used for recreational purposes in recent days.

\section{METHODS AND MATERIALS}

\section{a. Chemicals and Reagents}

All chemicals used for the toxin analysis was of HPLC grade, purchased from Sigma, Aldrich, USA. MCLR standards were received from the research collaborator, Robert Gordon University, UK.

\section{b. Study area and sampling}

The study was conducted in the Beira

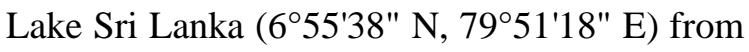
January 2013 to January 2014. Five sampling locations (Fig.1) were selected for the study and monthly sampling was done to collect water, bloom and phytoplankton samples. Samples were collected to sterilized clean glass bottles and transported to the laboratory kept in ice.

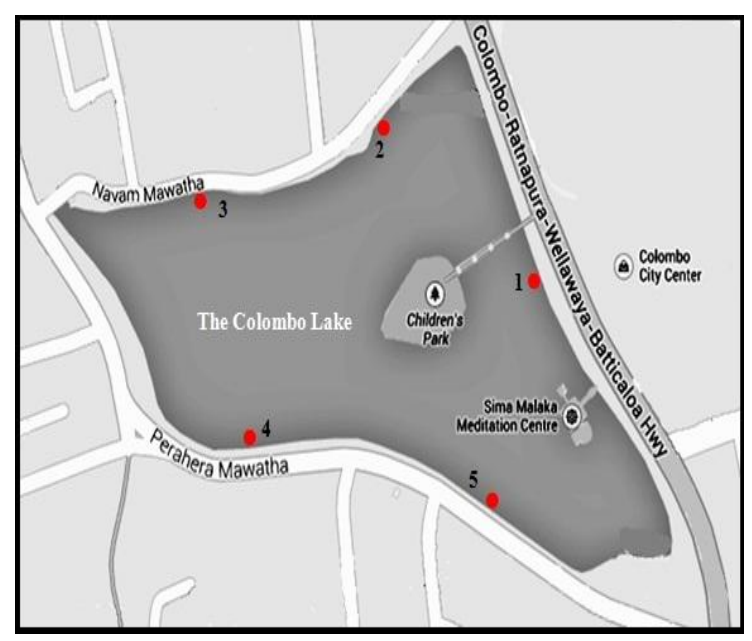

Figure1: sampling locations of the beira lake 


\section{c. Analysis of physico- chemical parameters}

The physico-chemical parameters of the collected surface water samples were analyzed. Water temperature $\left({ }^{0} \mathrm{C}\right)$, dissolved oxygen $(\mathrm{mg} / \mathrm{l}), \mathrm{pH}$ and electric conductivity $(\mu \mathrm{S} / \mathrm{cm})$ were measured at the site itself using thermometer (Immersion, Philip harris, England), DO meter (Oxi 320/ set, WTW Co., Weilheim, Germany), pH meter (330/ set ,WTW Co., Weilheim, Germany) and conductivity meter (340A/set ,WTW Co., Weilheim, Germany) respectively. Samples were kept in an ice box during transportation and stored in $4{ }^{\circ} \mathrm{C}$ until analysis. Total nitrate concentration $(\mathrm{mg} / \mathrm{l})$ and total phosphate concentration $(\mathrm{mg} / \mathrm{l})$ were measured according to standard spectrophotometric method (Silva et al. 1996).

\section{d. Analysis of biological parameters}

Chlorophyll-a concentration of the collected water samples were measured within 24 hours of sampling, according to standard spectrophotometric method described by Arvola(1981). Phytoplankton samples were collected by filtering 100 liters of water through $55 \mu \mathrm{m}$ plankton net and were fixed with acidified Lugals' solution at final concentration of $1 \%$ followed by natural sedimentation. Identification of cyanobacteria was carried out under light microscopy using standard keys (Prescot, 1978). Enumeration of cyanobacterial cell density was done using a shedwick rafter counting chamber under the light microscope (x 40).

\section{e. Extraction and quantification of Microcystin- LR}

Extraction of Microcystin-LR was extracted according to Lawton et al 1994. The collected scum samples were filtered through $0.2 \mu \mathrm{m}$ filter papers. The filter paper which contained cell bound microcystin component, were folded with the upper surface intermost, was placed in a suitable container and freeze thawed until extraction. Filter disks were placed in glass beakers containing $20 \mathrm{ml}$ of methanol and allowed for extraction for 1 hour at room temperature. The liqour was decant into a pear shaped rotary evaporator flask $(50 \mathrm{ml})$ and the filter was gently squeezed with a spatula to ensure maximum tranfer to the liquid. Then the sample was rotary evaporated at $400 \mathrm{C}$ in vacuo until dry. The residue was resuspended in $2 \mathrm{x}$ $250 \mu \mathrm{l}$ of methanol prior to analysis by PDAHPLC. The HPLC diode array was employed to analyses the extracted toxin concentration according to the method described by Lawton et al., 1994.

\section{F. Statistical analysis}

Pearsons correlation coefficient was calculated between each measured water quality parameter and total MC-LR concentration using the MINITAB software.

\section{RESULTS}

The present study recorded high levels of water temperature, $\mathrm{pH}$ and total phosphate during May 2013 (Table 1). DO value was highest during November 2013 and the lowest was recorded in December 2013. Both, water conductivity and total nitrate concentrations were recorded to be at the highest during December 2013. 
Table 1. Physico-chemical and biological parameters of the beira lake

\begin{tabular}{|l|l|l|l|l|l|l|l|}
\hline Month & $\begin{array}{l}\text { Water } \\
\text { temperatur } \\
\text { e (0C) }\end{array}$ & DO $(\mathrm{mg} / \mathrm{l})$ & $\mathrm{pH}$ & $\begin{array}{l}\text { Conductivi } \\
\text { ty }(\mu \mathrm{S} / \mathrm{cm})\end{array}$ & $\begin{array}{l}\text { N- } \\
\text { NO3(mg/l) }\end{array}$ & $\begin{array}{l}\text { Total } \\
\text { phosphate } \\
\text { concentratio } \\
\mathrm{mg}(\mathrm{l})\end{array}$ & $\begin{array}{l}\text { Chlorophyll-a } \\
\text { concentration } \\
(\mathrm{mg} / \mathrm{l})\end{array}$ \\
\hline January & $27.3 \pm 0.12$ & $4.21 \pm 0.14$ & $8.17 \pm 0.80$ & $215 \pm 0.65$ & $0.016 \pm 0.06$ & $0.189 \pm 0.003$ & $21.9 \pm 0.37$ \\
\hline February & $27.7 \pm 0.32$ & $5.48 \pm 0.22$ & $9.23 \pm 0.59$ & $303 \pm 0.14$ & $0.01 \pm 0.001$ & $0.198 \pm 0.005$ & $25.87 \pm 0.05$ \\
\hline March & $28.5 \pm 0.49$ & $5.93 \pm 0.03$ & $9.13 \pm 0.05$ & $298 \pm 0.78$ & $0.012 \pm 0.001$ & $0.156 \pm 0.001$ & $25.98 \pm 0.32$ \\
\hline April & $29.4 \pm 0.21$ & $5.93 \pm 0.001$ & $9.55 \pm 0.02$ & $293 \pm 0.07$ & $0.011 \pm 0.001$ & $0.178 \pm 0.05$ & $23.65 \pm 0.21$ \\
\hline May & $29.9 \pm 0.18$ & $6.01 \pm 0.21$ & $9.93 \pm 0.16$ & $256 \pm 1.35$ & $0.017 \pm 0.001$ & $0.298 \pm 0.03$ & $32.76 \pm 0.44$ \\
\hline June & $27.7 \pm 0.11$ & $5.72 \pm 0.03$ & $8.98 \pm 0.31$ & $267 \pm 0.89$ & $0.01 \pm 0.001$ & $0.167 \pm 0.01$ & $23.45 \pm 0.53$ \\
\hline July & $27.7 \pm 0.67$ & $5.89 \pm 0.06$ & $8.56 \pm 0.15$ & $245 \pm 2.05$ & $0.019 \pm 0.001$ & $0.149 \pm 0.01$ & $27.89 \pm 0.22$ \\
\hline August & $28 \pm 0.32$ & $3.11 \pm 0.11$ & $5.08 \pm 0.03$ & $415 \pm 2.06$ & $0.024 \pm 0.011$ & $0.132 \pm 0.05$ & $12.32 \pm 0.25$ \\
\hline September & $27.7 \pm 0.34$ & $5.09 \pm 0.03$ & $8.79 \pm 0.06$ & $238 \pm 0.05$ & $0.015 \pm 0.001$ & $0.155 \pm 0.09$ & $25.67 \pm 0.12$ \\
\hline October & $28 \pm 0.67$ & $6.11 \pm 0.57$ & $9.31 \pm 0.21$ & $249 \pm 0.98$ & $0.016 \pm 0.001$ & $0.129 \pm 0.01$ & $27.09 \pm 0.02$ \\
\hline November & $27.6 \pm 0.77$ & $6.18 \pm 0.41$ & $9.8 \pm 0.08$ & $238 \pm 0.32$ & $0.018 \pm 0.001$ & $0.141 \pm 0.07$ & $24.21 \pm 0.37$ \\
\hline December & $27.5 \pm 0.05$ & $2.98 \pm 0.03$ & $8.5 \pm 0.77$ & $524 \pm 0.44$ & $0.029 \pm 0.001$ & $0.121 \pm 0.08$ & $12.89 \pm 0.18$ \\
\hline January & $27.5 \pm 0.07$ & $4.65 \pm 0.32$ & $8.15 \pm 0.06$ & $223 \pm 0.58$ & $0.015 \pm 0.001$ & $0.132 \pm 0.04$ & $21.98 \pm 0.15$ \\
\hline
\end{tabular}

Toxin production varies greatly among different strains of the same species, genetic differences and metabolic processes may also be important in the production of these secondary metabolites (WHO). The analysis of phytoplankton composition of the lake recorded that Microcystis aeruginosa (M.aeruginosa), Microcystis wesenbergii (M.wesenbergii) and Microcystis incerta (M.incerta) were the toxin producing species present in the water body. Table 2 presents the percentages of $M$. aeruginosa, $M$. wesenbergii and $M$. incerta that were present during the sampling period. Moreover, Pediastrum duplex, Actinastarum sp, Scenedesmus armatus, Coelastrum $\mathrm{sp}$, and Chlorococcus sp were the non-toxic strians present in lake water.

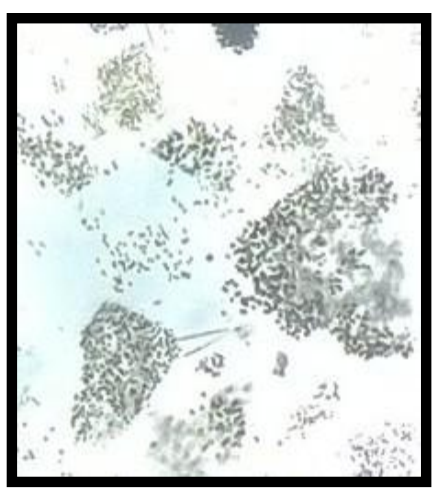

(a)

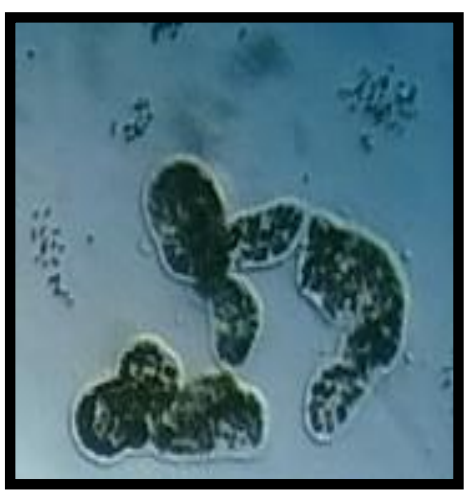

(b)

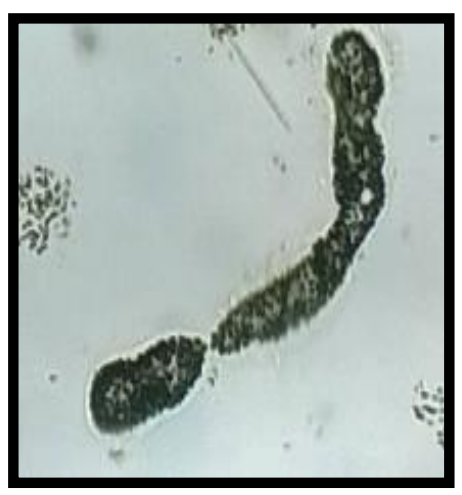

(c)

Figure 2. The dominant MC-LR producing species recorded
(a) M. aeruginosa (10x10)
(b) M.wesenbergii (10x10)
(c) Microcystis incerta (10x10) 
Table 2. Percentages of toxin producing Microcystis species during the sampling period.

\begin{tabular}{|c|c|c|c|}
\hline $\begin{array}{l}\text { Sampling } \\
\text { month }\end{array}$ & $\begin{array}{l}\text { M. } \\
\text { aeruginosa } \\
(\%)\end{array}$ & $\begin{array}{l}\text { M. } \\
\text { wesenbergii( } \\
\%)\end{array}$ & $\begin{array}{l}\text { M. } \\
\text { incerta } \\
(\%)\end{array}$ \\
\hline $\begin{array}{c}\text { January } \\
2013\end{array}$ & 36.52 & 30.48 & 33.00 \\
\hline February & 36.79 & 34.20 & 29.01 \\
\hline March & 36.41 & 33.15 & 30.43 \\
\hline April & 40.71 & 16.52 & 42.77 \\
\hline May & 48.86 & 21.79 & 29.35 \\
\hline June & 49.63 & 8.82 & 41.54 \\
\hline July & 36.97 & 33.24 & 29.79 \\
\hline August & 32.74 & 34.01 & 33.25 \\
\hline September & 35.00 & 32.37 & 32.63 \\
\hline October & 36.90 & 30.70 & 32.39 \\
\hline November & 34.09 & 36.62 & 29.29 \\
\hline December & 31.68 & 36.64 & 31.68 \\
\hline $\begin{array}{c}\text { January } \\
2014\end{array}$ & 35.87 & 30.43 & 33.69 \\
\hline
\end{tabular}

M.aeruginosa was the dominant species recorded and the highest percentage was recorded on June 2013 while the lowes was recorded on December 2013.

Fig.2 presents the chlorophyll-a concentrations and the total phytoplankton densities recorded. Highest Chlorophyll-a concentration was recorded in May 2013 while the lowest was recorded in August 2013. The total phytoplankton density showed a relationship with chlorophyll-a concentrations as total phytoplankton density was highest in May $2013\left(5.69 \times 10^{7}\right.$ cells $\left./ \mathrm{ml}\right)$ while in August it was at the lowest recording $2.65 \times 10^{7}$ cells $/ \mathrm{ml}$. Chlorophyll-a concentration has been used as an indicator to estimate microcystin levels in water bodies (Ha et al., 2011). However, the total chlorophyll-a concentration did not show a clear relationship with the total cyanobacterial density (Fig.3).

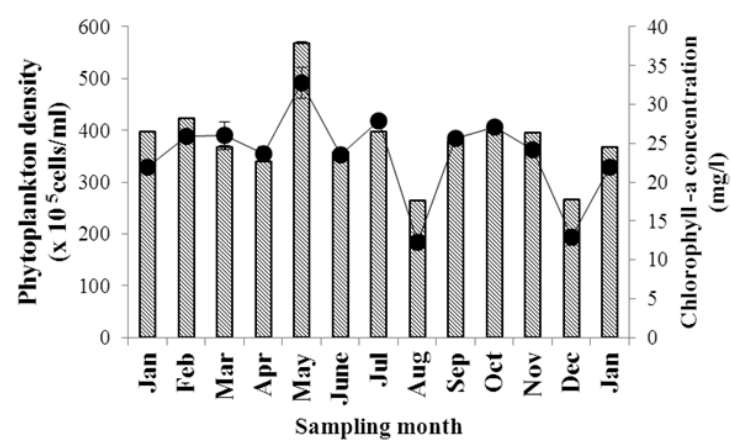

Figure 2. Chlorophyll-a concentrations and total phytoplankton cell densities

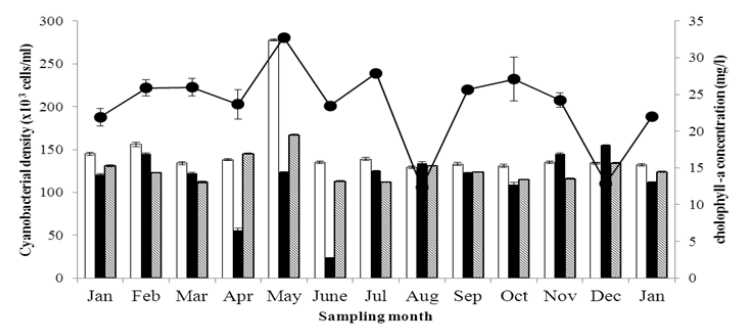

Figure 3. Chlorophyll-a concentrations and the cyanobacterial densities (Open bars- M.aeruginosa, Black bars- $M$. wesenbergii, hatched bars- $M$. incerta, closed circle- Chlorophyll-a concentrations)

The present study also records a variation of MC-LR concentration with respect to cyanobacterial densities. Fig. 4 presents that MC-LR concentration was recorded at maximum level $(25.23 \mu \mathrm{g} / \mathrm{ml})$ in May 2013, when M.aeruginosa cell counts were also at maximum $(2.78 \pm 0.15$ cells $/ \mathrm{ml})$. 


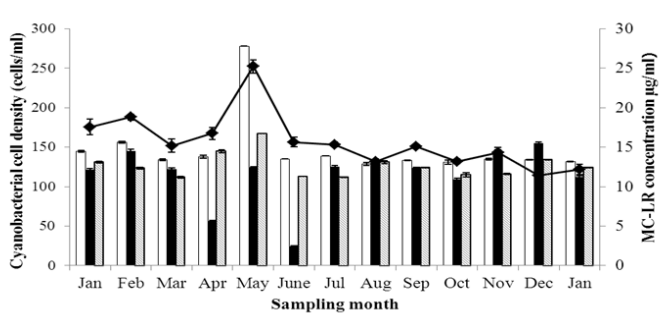

Figure 4. MC-LR concentration with respect to cyanobacterial cell densities (open barsM.aeruginosa, closed bars- M.wesenbergii, hatched bars- $M$. incerta, diamonds- MC-LR concentrations)

The Pearsons correlation coefficient calculated between measured water quality parameters and MCLR concentrations suggested that water temperature and the total phosphate concentration showed a strong positive relationship while the $\mathrm{pH}$ value of water showed a moderate correlation. The remaining parameters did not show a clear relationship with the toxin concentrations. The following table gives the Pearsons correlation coefficient values and the p-values gained.

Table 3. The Pearsons correlation coefficient values and the p-values between total MC-LR concentration and water quality parameters

\begin{tabular}{|c|c|c|}
\hline $\begin{array}{c}\text { Water quality } \\
\text { parameter }\end{array}$ & $\begin{array}{c}\text { Pearsons } \\
\text { correlation } \\
\text { coefficient }(\mathrm{r})\end{array}$ & $\mathrm{p}$-value \\
\hline $\begin{array}{c}\text { Water temperature } \\
\left({ }^{0} \mathrm{C}\right)\end{array}$ & 0.914 & 0.000 \\
\hline $\mathrm{pH}$ & 0.766 & 0.002 \\
\hline $\mathrm{DO}(\mathrm{mg} / \mathrm{l})$ & 0.422 & 0.151 \\
\hline $\begin{array}{c}\text { Conductivity } \\
(\mu \mathrm{S} / \mathrm{cm})\end{array}$ & -0.346 & 0.248 \\
\hline $\begin{array}{c}\text { Total N-nitrate } \\
(\mathrm{mg} / \mathrm{l})\end{array}$ & -0.375 & 0.206 \\
\hline $\begin{array}{c}\text { Total phosphate } \\
(\mathrm{mg} / \mathrm{l})\end{array}$ & 0.988 & 0.000 \\
\hline $\begin{array}{c}\text { Chlorophyll-a } \\
\text { concentration } \\
(\mathrm{mg} / \mathrm{l})\end{array}$ & 0.244 & 0.462 \\
\hline
\end{tabular}

The graphs (Fig.5) below indicates the scatter plots gained for the relationship between water temperature, $\mathrm{pH}$ and total phosphate concentration with total MC-LR concentration.

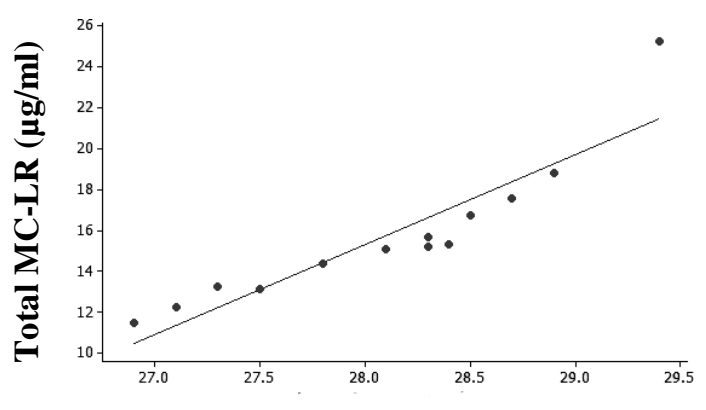

Water temperature $\left({ }^{\mathbf{0}} \mathrm{C}\right)$
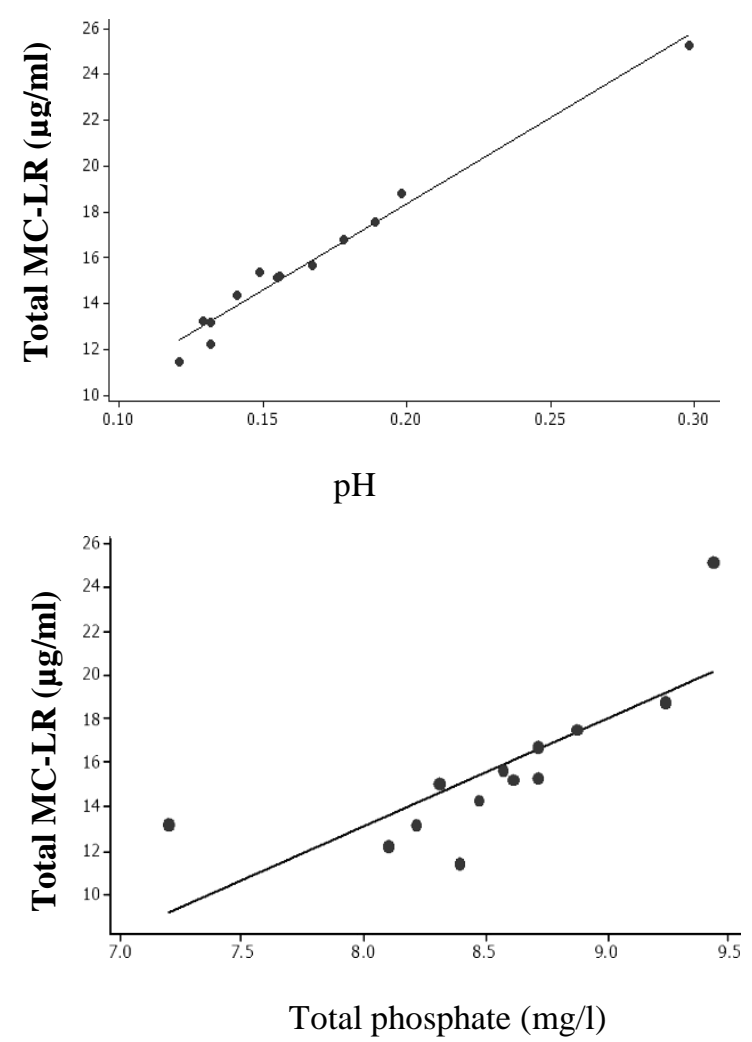


\section{DISCUSSION}

The factors inducing the production of toxins by cyanobacteria are not well known. Many studies have demonstrated that the chlorophyll-a concentration effect on toxin production. Interestingly the present study records that chlorophyll-a concentrations counts for both toxic and nontoxic species present in water. Thus, chlorophyll-a concentrations have no relationship with cyanobacterila cell density but shows a strong relationship to total phytoplankton density.

Furthermore, many laboratory studies have demonstrated that some of the same environmental factors as temperature, light, nitrogen concentrations, carbon availability (in the form of bicarbonate, carbonate and carbon dioxide), phosphate concentrations and $\mathrm{pH}$, could be important in toxin production (WHO).

Van der Westhuizen and Eloff (1983) recorded high toxicities when temperature levels were raised. In general, cyanobacteria prefer warm conditions, and low temperatures are one of the major factors that ends cyanobacterial blooms (Oberholster et al 2004). Furthermore Van der Westhuizen and Eloff (1983) determined that temperature has the most pronounced effect on toxicity. In addition the toxin levels were recorded to be high in elevated pH levels. Normally cyanobacterial blooms prevail in alkaline conditions. Song et al 1998 demonstrated that Microcystin production varies dramatically under different $\mathrm{pH}$ values. The present study records high levels of MC-LR at high temperature and $\mathrm{pH}$ as $\mathrm{p}$-values obtained during the pearsons correlation coefficient for temperature and $\mathrm{pH}$ were 0.000 and 0.002 respectively (Table 3 ).
MCLR concentrations were also positively correlated with the total phosphate concentration (Fig.5a), suggesting that progressive eutrophication (i.e. nutrient enrichment) of lakes by natural or anthropogenic activities (such as fertilizer runoff) may increase the quantity of MC-LR produced. The N-NO3 concentrations did not show any relationship to total toxin levels. According to Van der Westhuizen and Eloff 1983M. aeruginosa does not possess heterocysts, and it cannot fix atmospheric nitrogen in aerobic environments as do heterocystis genera such as Anabaena. Therefore Nitrogeon nor N-NO3 cannot be considered as a limiting factor in this situation.

Pilotto et al. (1997) reported that persons exposed for more than $1 \mathrm{~h}$ to recreational waters containing elevated concentrations of cyanobacteria $(>5000$ cells/ $\mathrm{mL}$ ) were more likely to report complications like repiratory problems. Moreover, studies of Backer et al 2010 suggests that people who were exposed to recreational waters contaminated with MCs had high concentrations of the toxins in their nasal swabs. The present study records high values for cyanobacterial cells and the values were greater than the $>5000$ cells $/ \mathrm{ml}$. Therefore, people who live around the lake and the recreational users are greatly exposed to high toxin levels which are prevailing in the Beira lake.

Thus, the study suggests that according to the climatic condition prevailing in Sri Lanka, MC-LR production of the cyanobacetrial species depend on the water temperature, $\mathrm{pH}$ and total phosphate concentrations. In addition the mean rainfall of the area can also effect on the toxin levels. 


\section{CONCLUSION AND FUTURE WORK:}

The study concludes that the MC levels in water exhibits a seasonal variation pattern specially with relevant to certain physicochemical parameters like water temperature, $\mathrm{pH}$ and total phosphate concentrations. These parameters can trigger algal bloom conditions and alternatively result in high toxin levels in water.

In future it is expected to study the diurnal effect on MC levels in water of the above lake.

\section{ACKNOWLEDGEMENT}

The authors wish to thank the National research council of Sri Lanka for the financial assistance provided under NRC; 11-034 grant.

\section{REFERENCES:}

CARMICHAET, W.W. (1995). Cyanobacterial toxins. In: Hallegraeff, G.M., Anderson, D.M., Cembella, A.D. (Eds.), Manual on Harmful Marine Microalgae.United Nations Educational, Scientific and Cultural Organisation, Paris.

CODD, G. A., S. G. BELL, AND W. P. BROOKS (1989). Cyanobacterial toxins in water. Water Sci. Technol. 21:1-13

IMANISHI, S., HARADA, K.: PROTEOMICS (2004). approach on microcystin binding proteins in mouse liver for investigation of microcystin toxicity. Toxicon 43, 651-659.

CARMICHAEL, W.W.: CYANOBACTERIA (1992). Secondary metabolites the cyanotoxins. J Appl Bacteriol 72(6), 445459.

CODD, G.A., WARD, C.J., BELL, S.G.: CYANOBACTERIAL TOXINS (1997). occurrence, modes of action, health effects and exposure routes. Arch ToxicolSuppl 19, 399-410.

JOCHIMSEN, E.M., CARMICHAEL, W.W. AN, J.S., CARDO, D.M.., COOKSON, S.T. (1998). Liver failure in death after exposure to microcystins at a hemodialysis center in Brazil. N. Engl. J. Med., 338, 873-878.

YU, S. BLUE-GREEN ALGAE AND LIVER CANCER. IN: STEFFENSEN, D.A., NICHOLSON, B.C. (EDS.) (1994). Toxic Cyanobacteria: Current Status of Research and Management. Australia Center for Water Quality Research, Salisbury, Australia.

EBENSTEIN, AVRAHAM. (2012). "The consequences of industrialization: evidence from water pollution and digestive cancers in China." Review of Economics and Statistics 94.1: 186-201.

NGWA, F. F., MADRAMOOTOO, C. A., JABAJI, S. (2014). Comparison of cyanobacterial microcystin synthetase (mcy) E gene transcript levels, mcy E gene copies, and biomass as indicators of microcystin risk under laboratory and field conditions. Microbiology Open.

PHILLIP, R., BATES, A.J. (1992). Health risks assessment of dinghy sailing in Avon and exposure to cyanobacteria (blue-green algae). J. Inst. Water Environ. Manage. 6, 613-620.

STEWART, I., WEBB, P.M., SCHLUTER, P.J., FLEMING, L.E., BURNS JR., J.W., GANTAR, M., BACKER, L.C., SHAW, G.R. (2006b). Epidemiology of recreational exposure to freshwater cyanobacteriadan international prospective cohort study. BMC Public Health 6 (93). Doi: 10.1186/14712458-6-93.

WICKS, R.J., THIEL, P.G. (1990). Environmental factors affecting the production of peptide toxins in floating 
scums of the cyanobacterium Microcystis aeruginosa in a hypertrophic African reservoir. Environ. Sci. Technol. 24: 14131418

SIVONNEN,K. (1990). Effects of light, temperature, nitrate, orthophosphate, and bacteria on growth of and hepatotoxin production by Oscillatoria agardhii strains. Appl. Environ. Microbiol. 56: 2658-2666

GORHAM, P. R.: TOXIC ALGAE. IN JACKSON, D. F. (ED.) (1964). Algae and Man. Plenum Press, pp. 307-36 New York,

RUNNEGAR, M. T. C., FALCONER, I. R., JACKSON, A. R. B., MCINNES, A. (1983). Toxin production by Microcystis aeruginosa cultures. Toxicon (Suppl.) 3377

VAN DER WESTHUIZEN, A. J., ELOFF, J. N. (1983). Effect of culture age and $\mathrm{pH}$ of culture medium on growth and toxicity of the blue-green alga Microcystis aeruginosa. Z. Pflanzenphysiol. 110:157-163

WATANABE, M. F., OISHI, S. (1985). Effects of environmental factors on toxicity of a cyanobacterium (Microcystis aeruginosa) under culture conditions. Appl. Environ. Microbiol. 49, 1342-4

OHTAKE, A., SHIRAI, M., AIDA, T., MORI, N., HARADA, K.-I., MATSUURA, K., SUZUKI, M. AND NAKANO, M. (1989). Toxicity of Microcystis species isolated from natural blooms and purification of the toxin. App. Environ. Microbiol. 55: 3202 - 3207

CARMICHAEL, W.W.: ALGAL TOXINS. IN: CALLOW, J.A. (1986). Advances in Botanical Research. London: Academic Press. $47-101$

WATANABE, M. F., HARADA, K., MATSUURA, K., WATANABE, M., SUZUKI. M. (1989). Heptapeptide toxin production during the batch culture of two Microcystis species (Cyanobacteria). J. Appl. Phycol. 1:161-165
CODD, G. A., POON, G. K. (1988). Cyanobacterial toxins, p. 283-296. In L. J. Rogers and J. R. Gallon (ed.), Biochemistry of the algae and cyanobacteria. Proceedings of the Phytochemistry Society of Europe, vol. 28. Oxford University Press, Oxford

MAGANA-ARACHCHI, D.N., WANIGATUNGE, R.P., Jeyanandarajah, P. (2008). Setting up a Polymerase Chain Reaction Assay for the Detection of Toxic Cyanobacteria., Journal of National Science Foundation. 36(3):229-234

SILVA, E.I.L., NAMARATHNE, S.Y., WEERASOORIYA, S.V.R., MUNAWEERA, L. (1996). Water analysis user friendly field / laboratory manual, Aj prints, Dehiwala, Sri lanaka

ARVOLA, L. (1981). Spectrophotometric determination of chlorophyll-a and phaeopigments in ethanol extractions. Ann Bot Fennici. 18:221-227

PRESCOTT, G. W. (1978). How to Know the Freshwater Phytoplankton, 3rd ed. Cambridge University Press, Cambridge, $348 \mathrm{pp}$

LAWTON, L. A., EDWARDS, C., CODD, A. (1994). Extraction and high-performance liquid chromatographic method for the determination of microcystins in raw and treated waters. Analyst 119:1525-1530

WHO GUIDELINES, Background document for development of Drinking-water Quality Cyanobacterial toxins: Microcystin-LR in Drinking-water

HA, J.H., HIDAKA, T AND TSUNO, H. (2011 Feb.) Analysis of factors affecting the ratio of microcystin to chlorophyll-a in cyanobacterial blooms using real-time polymerase chain reaction. Environ Toxicol; 26(1): 21-8.

OBERHOLSTER, P. J. (2004). Assessing genetic diversity and identification of 
Microcystis aeruginosa strains through AFLP and PCR-RFLP analysis. M.Sc. Thesis, University of the Free State, Bloemfontein, p. 114

SONG, L.R., SANO, T., LI, R.H., MAKOTO, W.M., LIU, Y.D., KAYA,K. (1998). Microcystin production of Microcystis viridis (cyanobacteria) under different culture conditions. Phycology Research 42, 19- 23

PILOTTO, L.S., DOUGLAS, R.M., BURCH, M.D., CAMERON, S., BEERS, M., ROUCH, G.J., ROBINSON, P., KIRK, M., COWIE, C.T., HARDIMAN, S., MOORE, C.,Attewell, R.G. (1997). Health effects of exposure to cyanobacteria (blue-green algae) during recreational water-related activities. Aust. N.Z. J. Public Health 21, 562-566

BACKER, LORRAINE C.,et. al. (2010). "Recreational exposure to microcystins during algal blooms in two California lakes." Toxicon 55.5: 909-921 